\title{
Keanekaragaman Serangga Hama dan Musuh Alami pada Lahan Pertanaman Kedelai di Kecamatan Balong-Ponorogo
}

\author{
INDRIYA RADIYANTO, MOCHAMMAD SODIQ DAN \\ NOENG M. NURCAHYANI
}

Fakultas Pertanian UPN "Veteran" Jawa Timur

(diterima Februari 2010, disetujui Juli 2010)

\begin{abstract}
Biodiversity of Insect Pests and Natural Enemies on Soybean In The Field of Balong-Ponorogo District. The study aims to determine the presence of pests and natural enemies on soybean plants and to study the effect of insecticides on the diversity. Methods for observation of insects was done by using different type of traps i.e. yellow pan trap, pitfall trap, light trap, sweeping net and direct observation (visual). The presence of pests and natural enemies of soybean plants on plots without insecticide was lower than on the plots that was treated with insecticide. Composition of the population of pests found in soybean plots that were not treated with insecticide were dominated by Aphis sp. followed by Phaedonia inclusa, Riptortus linearis, Nezara viridula and Ophiomyia phaseoli. Composition of the population of natural enemies (predators) found in soybean cropps that were not treated with insecticide was family Coccinellidae followed by Syrphidae, Chrysopidae, Mantidae and Oxyopidae. The highest composition of natural enemies (parasites) found in treated and untreated soybean plots were family Braconidae then followed by family Ichneumonidae.
\end{abstract}

KEY WORDS: Diversity, pests, predators and parasites

\section{PENDAHULUAN}

Produksi kedelai nasional tahun 2008 sebesar 671.600 ton dengan luas lahan 526.796 Ha. Data di atas menunjukkan bahwa produksi kedelai di Indonesia berkisar antara 1-1,5 ton/Ha. Hasil tersebut hanya memenuhi 40 persen dari kebutuhan dalam negeri. mencapai 1.679 .400 ton sehingga kita harus mengimpor kedelai sedikitnya 1 juta ton/tahun. Lonjakan import kedelai disebabkan oleh pe- ningkatan konsumsi produk industri kecil seperti tahu, tempe, kecap, dan susu semakin populer sebagai pengganti daging. Jenis industri yang tergolong skala kecil-menengah ini jumlahnya sangat banyak, menyebabkan tingginya tingkat kebutuhan konsumsi kedelai (Anonim 2004; Anonim 2010).

Salah satu kendala upaya peningkatan produksi kedelai adalah adanya serangan berbagai hama. Tanaman kedelai merupakan salah satu tanaman yang dapat diserang hama 
sejak mulai tumbuh hingga menjelang panen. Di Indonesia tercatat lebih dari 111 spesies Arthropoda merupakan hama, 53 spesies merupakan bukan sasaran, 61 spesies predator dan 41 spesies parasitoid (Okada et al. 1988). Tercatat 17 jenis hama yang dapat menyebabkan kerusakan dan kerugian pada tanaman kedelai. Beberapa hama utama yang sering ditemukan adalah lalat kacang (Ophiomyia phaseoli), ulat grayak (Spodoptera litura), Kumbang daun tembukur (Phaedonia inclusa), penggerek polong (Etiella zinckenella), penghisap polong (Riptortus linearis), dan kepik hijau (Nezara viridula) (Anonim 1992).

Dalam upaya untuk mengendalikan hama, petani sekarang masih bertumpu pada insektisida, karena cara-cara yang lain seperti penggunaan varietas tahan dan musuh alami belum banyak digunakan. Pengendalian hama menggunakan insektisida sudah biasa di lakukan, tetapi kegagalan dalam menanggulangi hama masih sering terjadi. Penggunaan insektisida tanpa didasari pengetahuan bioekologi hama dan teknik aplikasi yang benar mengakibatkan tidak tercapainya tujuan pengendalian, bahkan dapat menyebabkan terjadinya kasus resistensi dan resurjensi (Marwoto 1992).

Untuk mengurangi dampak negatif penggunaan pestisida tersebut, maka pengendalian hama secara konvensional (menggunakan pestisida) mulai ditinggalkan dan beralih pada pe- ngendalian berdasarkan konsepsi pengelolaan hama terpadu (PHT). Untung (1993) menyatakan bahwa PHT lebih mengutamakan pengendalian dengan memanfaatkan peran berbagai musuh alami hama. Musuh alami pada keseimbangan alam yang baik selalu berhasil mengendalikan populasi hama, tetap berada di bawah aras ekonomi. Oleh karena itu, dengan memberikan kesempatan kepada musuh alami untuk bekerja berarti dapat mengurangi penggunaan pestisida. Mengingat peran parasit dan predator dalam menekan populasi hama secara alami cukup penting, maka upaya konservasi musuh alami di lapang perlu lebih diperhatikan.

Penelitian ini bertujuan untuk mengeksplorasi dan mengetahui keberadaan hama dan musuh alami pada lahan tanaman kedelai yang menggunakan insektisida maupun tanpa insektisida.

\section{BAHAN DAN METODE}

Penelitian ini dilaksanakan mulai Agustus 2004 sampai dengan Oktober 2004 di Desa Balong, Kecamatan Balong, Kabupaten Ponorogo.

Penelitian ini menggunakan metode survei, yaitu melakukan pengamatan secara langsung (visual) dan penangkapan dengan menggunakan alat perangkap seperti yellow pan trap, pitfall trap, sweep net, light trap pada lahan pertanaman kedelai. Lahan pertanaman kedelai yang diamati adalah 
lahan tanpa penyemprotan insektisida dan lahan yang disemprot insektisida dua minggu sekali. Jenis insektisida dengan bahan aktif deltametrin dan metoksifenosida dosisnya mengacu dosis yang biasa digunakan petani di daerah tersebut.

Masing-masing petak contoh (luas berkisar $500 \mathrm{~m}^{2}$ per petak contoh) diulang tiga kali pada tiga lokasi, setiap lokasi berada pada desa yang berbeda dalam satu kecamatan. Serangga yang tertangkap / ditemukan di lapangan dihitung dan diidentifikasi, kemudian ditentukan pula komposisi populasi dari masing-masing hama atau musuh alami. Pengamatan dilakukan setiap satu minggu sekali, pada fase vegetatif $7-42$ hari setelah tanam (hst) dan fase generatif $49-77$ hst.

\section{HASIL DAN PEMBAHASAN}

\section{Jenis Hama dan Musuh Alami}

Hasil pengamatan dan identifikasi terdapat beberapa spesies hama dan beberapa famili musuh alami. Hama yang didapatkan adalah yang menyerang daun dan polong. Beberapa famili dari predator dan parasitoid yang tertangkap adalah: Coccinelidae, Syrphidae, Chrysopidae, Oxyopidae, dan Mantidae untuk predator, sedangkan untuk parasitoid ditemukan dua famili yaitu: Ichneumonidae dan Braconidae.

\section{Komposisi Hama}

Hasil penelitian menunjukan adanya perbedaan komposisi keberadaan populasi hama dan musuh alami yang ditemukan pada pertanaman kedelai di Kecamatan Balong Kabupaten Ponorogo (Gambar 1). Data yang diperoleh menunjukkan bahwa dari lima spesies hama yang ditemukan, Aphis sp. memiliki kerapatan populasi tertinggi dibanding hama lain, seperti Phaedonia inclusa, Riptortus linearis, Nezara viridula dan Ophiomyia phaseoli, pada lahan pertanaman kedelai tanpa perlakuan insektisida (A) berturut-turut sebesar $44 \%, 15 \%$, $14 \%, 14 \%$ dan $13 \%$. Demikian juga pada lahan pertanaman kedelai yang disemprot insektisida 2 minggu sekali (B), Aphis spp. memiliki kerapatan populasi tertinggi kemudian diikuti oleh Phaedonia inclusa, Nezara viridula, Riptortus linearis dan Ophiomyia phaseoli berturut-turut sebesar $47 \%, 20 \%, 14 \%, 11 \%$ dan 8 \%. Keberadaan populasi Aphis sp. yang lebih tinggi dibandingkan jenis hama lain karena di daerah tropis serangga ini dapat berkembang biak tanpa melalui perkawinan, sehingga populasinya dapat meningkat dengan cepat. Aphis spp. berkembang biak dengan parthenogenesis (Anonim 1989). Selain itu menurut Trisyono (2006) meningkatnya populasi hama bukan hanya karena penyederhanaan 

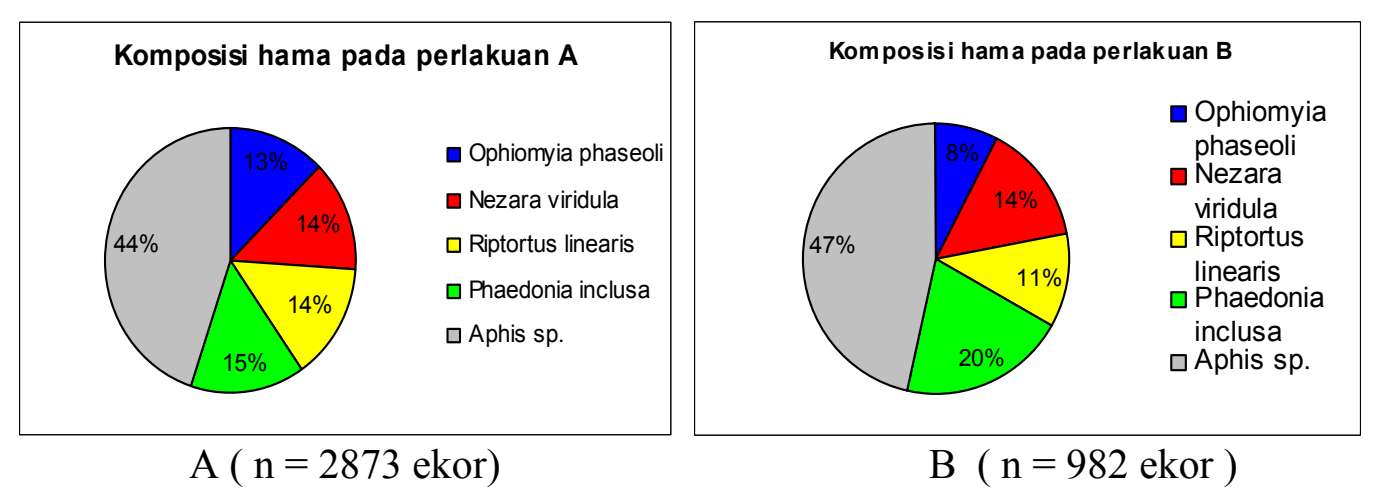

Gambar 1. Komposisi hama pada kondisi lahan pertanaman kedelai A. tanpa insektisida dan B. disemprot insektisida 2 minggu sekali
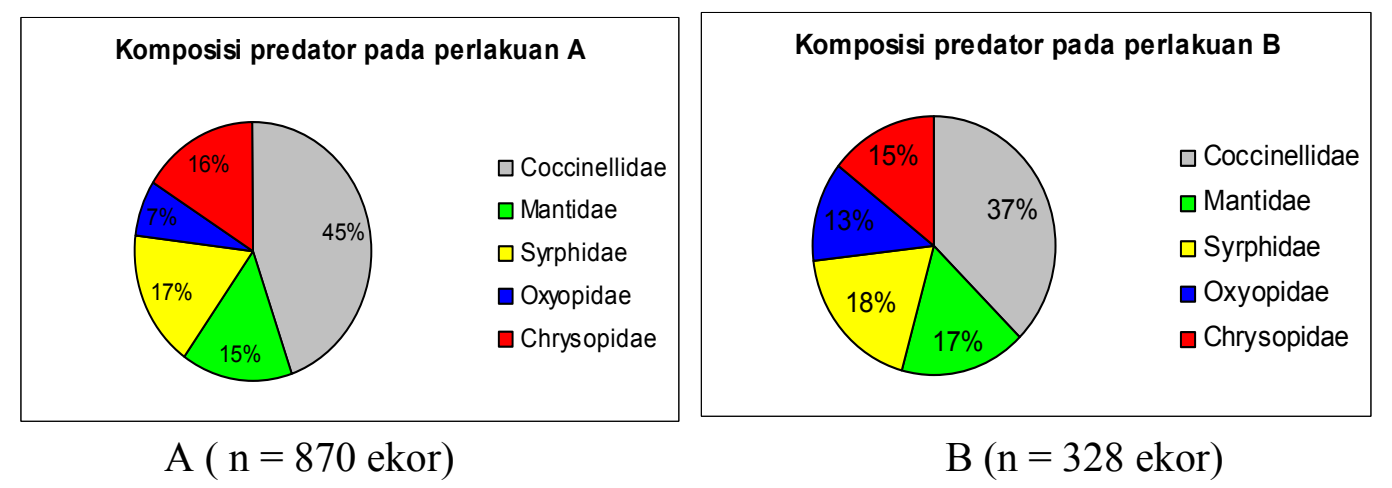

Gambar 2. Komposisi predator pada lahan pertanaman kedelai A. tanpa insektisida dan B. disemprot insektisida 2 minggu sekali

tanaman tetapi juga karena penggunaan pestisida yang tidak bijaksana. Contohnya adalah hama ulat grayak Spodoptera exigua pada tanaman bawang telah resisten dengan insektisida berbahan aktif metoksifenosida

\section{Komposisi Musuh Alami (Predator)}

Pada Gambar 2 dapat diperhatikan bahwa predator yang paling dominan dari lima famili yang ditemukan di lapang adalah Famili Coccinellidae. Pada lahan pertanaman kedelai tanpa insektisida (A) paling banyak di- temukan Famili Coccinellidae kemudian diikuti Syrphidae, Chrysopidae, Mantidae dan Oxyopidae, berturut-turut sebesar $45 \%, 17 \%, 16 \%$, $15 \%$ dan $7 \%$. Demikian juga pada lahan pertanaman kedelai yang diperlakukan dengan insektisida 2 minggu sekali (B) ditemukan paling banyak famili Coccinellidae kemudian diikuti Syrphidae, Mantidae, Chrysopida dan Oxyopidae berturut-turut sebesar $37 \%, 18 \%, 17 \%, 15 \%$ dan $13 \%$. Tingginya populasi Coccinellidae pada pertanaman kedelai di- 
sebabkan predator Coccinelidae memiliki sifat oligofagus, memakan beberapa jenis serangga kecil tertentu, misalnya kutu daun dan tungau dari berbagai stadia telur, nimfa maupun imago. Menurut Untung (1993), Coccinellidae selain imago, larvanya juga aktif mencari mangsa dan biasanya lebih rakus dari pada imago. Mangsa yang ditangkap akan dihisap cairan tubuhnya, bangkainya akan dibuang dalam keadaan kering. Pada pertanian yang tidak menggunakan pestisida, jenis dan populasi Artropoda lebih banyak daripada yang mengaplikasikan pestisida. Kasus tersebut berlaku baik areal pada tanam serempak maupun tanam tidak serempak (Laba et al. 2000).

\section{Komposisi Parasitoid}

Gambar 3 menunjukkan bahwa Famili Braconidae memiliki kepadatan tertinggi untuk parasitoid hama pada tanaman kedelai, kemudian diikuti famili Ichneumonidae. Hal tersebut ditunjukkan pada lahan pertanaman kedelai tanpa insektisida (A) berturutturut sebesar 68 dan $32 \%$. Pada lahan pertanaman kedelai yang disemprot insektisida 2 minggu sekali (B) berturut-turut sebesar 56 dan $44 \%$.

\section{KESIMPULAN}

Hama maupun musuh alami pada tanaman kedelai pada lahan tanpa perlakuan insektisida populasinya lebih rendah dibanding lahan yang diperlakukan dengan insektisida. Komposisi sebaran populasi hama yang ditemukan pada lahan pertanaman kedelai yang diperlakukan maupun tidak dengan insektisida tertinggi Aphis sp. kemudian Phaedonia inclusa, Riptortus linearis, Nezara viridula dan Ophiomyia phaseoli. Komposisi sebaran populasi predator yang ditemukan pada lahan pertanaman kedelai yang diperlakukan maupun tidak dengan insektisida tertinggi Famili Coccinellidae kemudian diikuti Syrphidae, Chrysopidae, Mantidae dan Oxyopidae.

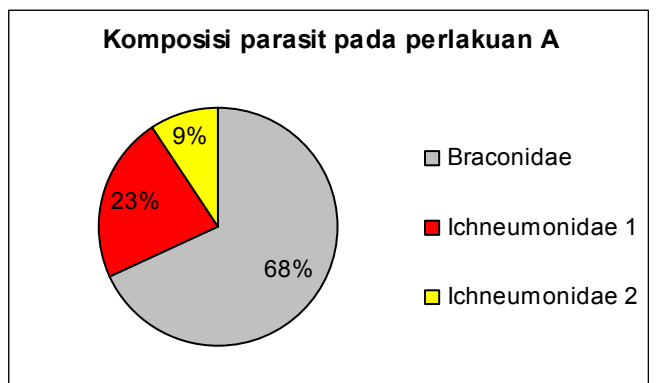

A $(n=148$ ekor $)$
Komposisi parasit pada perlakuan $B$

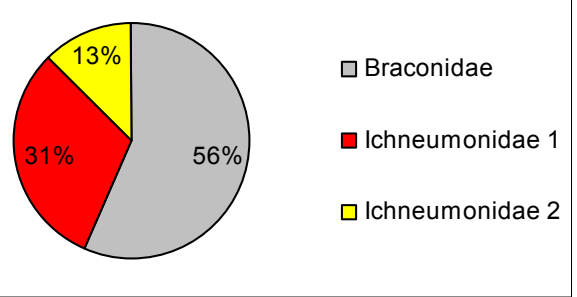

$$
\text { B ( } \mathrm{n}=65 \text { ekor })
$$

Gambar 3. Komposisi parasitoid pada lahan pertanaman kedelai

A. tanpa Insektisida dan B. disemprot insektisida 2 minggu sekali 
Komposisi sebaran padat parasitoid yang ditemukan pada lahan pertanaman kedelai yang diperlakukan maupun tidak dengan insektisida tertinggi famili Braconidae kemudian famili Ichneumonidae.

\section{DAFTAR PUSTAKA}

[Anonim]. 1989. Kedelai. Yogyakarta: Kanisius. . 1992. Dominasi dan Tingkat Serangan Hama Kedelai. Risalah Lokakarya Pengendalian Hama Terpadu Tanaman Kedelai. Balittan. Malang. Hal. 29-35. . 2004. Vegetable Soybean Production. AVRDC Insect Pests Manajemen. http:// www. Avrdc. org/vegetable soybean production,ipm.htm. [diakses Februari 2010]

2010. Kedelai. http://id. wikipedia.org/wiki/Kedelai. [diakses Februari 2010]

Kalshoven, L G E. 1981. Pest of Crop in Indonesia. Jakarta: PT. Ichtiar Baru - Van Hoeve.

Laba, I. W., Djatnika K. dan M. Arifin. 2000. Analisis Keanekaragaman Hayati Musuh Alami Pada Ekosistem Padi Sawah. Di dalam: E. Soenarjo et al. (ed.),
Prosiding Simposium Keanekaragaman Hayati Arthropoda pada Sistem Produksi Pertanian; Cipayung, 16-18 Oktober 2000. PEI-KEHATI.

Marwoto. 1992. Masalah Efektifitas Pengendalian Hama Kedelai di Tingkat Petani. Risalah Lokakarya Pengendalian Hama Terpadu Tanaman Kedelai. Balittan. Malang. Hal. 37-43.

Okada, T., W. Tengkano and T. Djuwarso. 1988. An Outline of Soybean Pest In Indonesia In Faunistic Aspect. Di dalam: Seminar BORIF; Bogor, 6 Desember 1988. Bogor: BIORIF p. 37

Siwi, S. S., 1993. Kunci Determinasi Serangga. Yogyakarta: Penerbit Kanisius.

Trisyono, Y. A. 2006. Refleksi dan Tuntutan Perlunya Manajemen Pestisida. Pidato Pengukuhan Guru Besar UGM Yogyakarta.

Untung K. 1993. Pengantar Pengelolaan Hama Terpadu. Yogyakarta: Gajah Mada University Press. 